
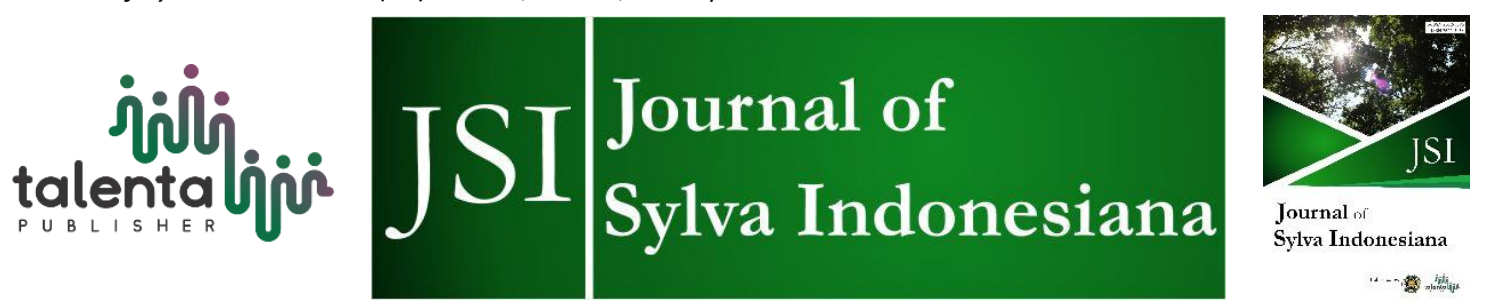

\title{
Study of the Potential and Development of Riam Sabada Natural Tourism Attractions in Sebatih Village Sengah Temila District Landak Regency West Kalimantan Province
}

\author{
Slamet Rifanjani ${ }^{1}$, Sesilia Indah Saptri ${ }^{1 *}$, and Muflihati ${ }^{1}$ \\ ${ }^{1}$ Fakultas Kehutanan, Universitas Tanjungpura, Jl. Daya Nasional, Pontianak 78124, Indonesia
}

\begin{abstract}
Riam Sabada is one of the natural attractions in Landak Regency in the form of water flow over rocks with unspoiled nature and flora and fauna that potential to become tourist attractions. A potential assessment is carried out to find out whether the tourism object is the potential to be developed or not. Riam Sabada is one of the natural attractions in the Landak Regency, West Kalimantan Province. The study was conducted in October 2020 using observation and interview methods to 10 respondents selected by purposive sampling, which was determined intentionally by researchers. The respondent's criteria were community leaders, had ever visited tourist objects, and had knowledge about Riam Sabada tourism. Data were analyzed using Microsoft Excel. Riam Sabada's ODTWA potential assessment results in a score of 460.27 , which was included in the classification as possible enough to be developed. The unspoiled cascade area was surrounded by shady trees, large rocks, and flora and fauna such as civets, birds, melaban, and orchids. Riam Sabada's natural tourism development strategy was to implement policies that support an aggressive strategy (SO strategy) where the strategy was in a favorable position because it maximized the strengths and opportunities of the tourist attraction. However, to support development, it was necessary to build facilities and infrastructure and to study the carrying capacity of the Riam Sabada tourist attraction.
\end{abstract}

Keyword: SWOT Analysis, Purposive Sampling, Riam Sabada, Aggressive Strategy

Received 10 July 2021 | Revised 22 September 2021 | Accepted 15 January 2022

\section{Introduction}

Tourism potential assessment is the process of assessing tourist attraction in the form of natural potential and artistic potential [1]. Tourism potential is a variety of resources owned by a place developed into the tourist attractions utilized for economic purposes while still paying attention to other aspects [2]. Therefore, assessments made on tourism nature to know that the tourism object is quite potent and has the opportunity to be developed.

\footnotetext{
*Corresponding author at: Fakultas Kehutanan, Universitas Tanjungpura, Jl. Daya Nasional, Pontianak 78124, Indonesia

E-mail address: sesiliasaptri01@gmail.com
} 
Natural attractions can be in the form of lakes, landscapes, beaches, mountains, temples, monuments, cascades, waterfalls, and others [3]. Landak Regency has many cascades and waterfalls tourism potential that has the prospect, including Riam Angan Tembawang [4], Mananggar Waterfall [5], and Dait Waterfall [6]. Riam Sabada, located in Keranji Birah Hamlet, Sebatih Village, Sengah Temila District, Landak Regency, is one of the natural attractions of the waterfall. The study was conducted to assess its development potential. Shady trees and large rocks surround the area with the unspoiled cascade, and there are many flora and fauna such as ferrets, birds, melaban, orchids, and others. The criteria for tourist attraction in Riam Sabada have a score of 915.84 or a reasonably good category [7]. Other criteria were assessed to determine the development potential of Riam Sabada Natural Tourism Attraction (ODTWA).

Assessment of potential natural tourism attraction objects (ODTWA) consists of attractiveness criteria, accessibility, socio-economic, environmental conditions, accommodation, supporting facilities and infrastructure, and the availability of clean water [8]. Attractiveness is the main factor that allows visitors to come, while the other criteria support the main factor. The development of natural tourism is based on the potential value in the location. Tourism development planning must be comprehensive, therefore all aspects of tourism development are taken into account by considering the calculation of profit and loss compared to the development of other sectors [9]. This study was conducted to assess the potential and develop a strategy for developing nature tourism in Riam Sabada Hamlet, Keranji Birah, Sebatih Village, Sengah Temila District, Landak Regency.

\section{Research Method}

The research was carried out in Riam Sabada, Keranji Birah Hamlet, Sebatih Village, Sengah Temila District, Landak Regency in October 2020. Geographically, Riam Sabada is located at coordinates $0.270532 \mathrm{~N}$ and $109.678936 \mathrm{E}$ and is situated between three hamlets, namely Hamlet Kepayang, Hamlet Keranji Birah, and Hamlet Bingge, but the entrance to the tourist attraction is in Hamlet Keranji Birah. The tools used were a location map with a scale of 1:100,000, a questionnaire, a cellphone camera, and a 2003 ADO-ODTWA assessment guidebook from the Director-General of PHKA. The methods were observation and interviews with respondents selected by purposive sampling, which was determined intentionally by the researcher. The respondent's criteria were the community leaders, had ever visited tourist objects, and had knowledge about Riam Sabada tourism. The respondents were ten people: the community, village government, stakeholders, and principals of elementary/junior/high school in Riam Sabada. Data were analyzed using Microsoft Excel. The main elements of potential assessment criteria were (1) Attractiveness; (2) Accessibility; (3) socioeconomic and environmental conditions; (4) Accommodation; (5) Supporting facilities and infrastructure; and (6) Availability of clean water. The formula calculates the total value of each criterion: 


$$
S=N \times B
$$

Keterangan: $\quad S=$ Score or value of a criterion

$$
\begin{aligned}
& \mathrm{N}=\text { The number of element values in the criteria } \\
& \mathrm{B}=\text { Weighted value }
\end{aligned}
$$

The assessment results of each element of each tourist attraction criteria are averaged to obtain the final score. Then a comparison is made with the classification of development elements based on the value and weighted-score (Table 1). The assessment is obtained based on the subelements found at the research location, then multiplied by the weight of each criterion according to the Guide to Analysis of Operational Areas and Nature Tourism Attractions (ADOODTWA) Directorate General of Forest Protection and Nature Conservation (PHKA) 2003 [8].

Table 1 Classification of Development Elements Based on Average Value x Weight of Each Assessment Criterion

\begin{tabular}{ccl}
\hline No & Total Score & Elemental Potency Assessment \\
\hline 1 & $518-667$ & Potential to be developed (A) \\
2 & $370-517$ & Potential Enough to be developed (B) \\
3 & $220-369$ & Poor possibility to be developed (C) \\
\hline Data source: Modification of ADO-ODTWA PHKA 2003
\end{tabular}

In the case of potential assessment was in the category of potential to be developed (A) or sufficiently potential to be developed (B), a SWOT analysis will be carried out to formulate a development strategy. SWOT analysis is the process of detailing the state of the internal and external environment to determine the factors that are the key to success into the categories of Strengths, Weaknesses, Opportunities, and Threats.

\section{Results and Discussion}

Riam Sabada is one of the cascade tourism potentials in Keranji Birah Hamlet, Sebatih Village, Sengah Temila District, Landak Regency (Figure 1). The distance from the capital city of Sengah Temila District to the tourist attraction is approximately 30 minutes. Based on interviews with managers, this attraction receives many tourists at the end of every year. 


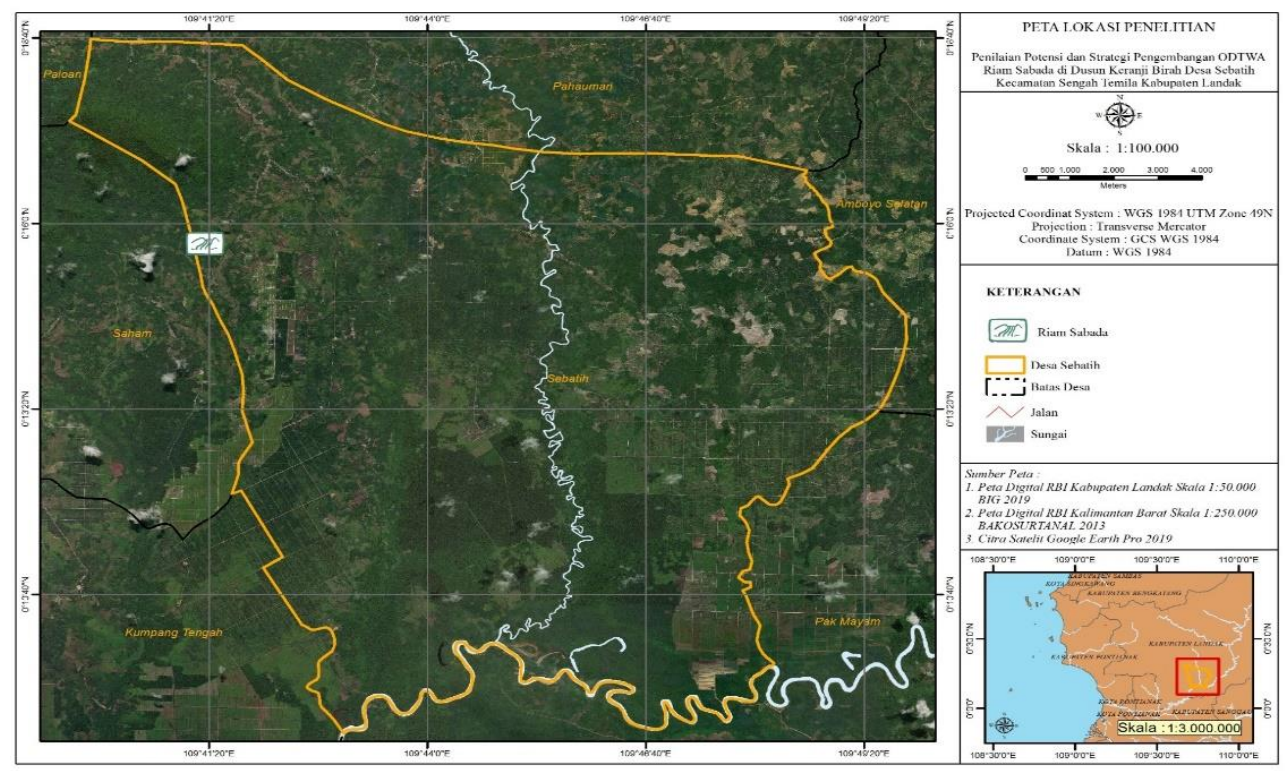

Figure 1 Research location map

The assessment of Riam Sabada's ODTWA potential was carried out based on six criteria with a score of 460.27 (Table 2). It means that Riam Sabada has had enough potential to be developed (B). Of the six assessed criteria, one was of potential to be developed (A), two were potential enough (B), and three were of poor value (C).

Table 2 Results of Riam Sabada Nature Tourism Attraction Assessment

\begin{tabular}{clll}
\hline No & Element & Score (Weight Value) & Description \\
\hline 1 & Attractiveness & $915.84^{*}$ & $\mathrm{~B}^{*}$ \\
2 & Accessibility & 300 & $\mathrm{~B}$ \\
3 & Socioeconomic and Environmental & 585.7 & $\mathrm{C}$ \\
4 & Condition & 0 & $\mathrm{C}$ \\
5 & Accommodation & 94.29 & $\mathrm{C}$ \\
6 & Aupporting Infrastructure & 865.74 & $\mathrm{~A}$ \\
\hline & $\quad$ Total Value x Weight & $2,761.57$ & \\
& $\quad$ Average & 460.27 & $\mathrm{~B}$ \\
\hline
\end{tabular}

Data source: Results of interviews and observations, 2020. Description: $*=$ Wigo et al. (2020)

\subsection{Attractiveness}

The attractiveness assessment consists of eight elements and 42 sub-elements, resulting in a value of 915.84, which is included in the potential enough category (B) [7]. The Riam Sabada area has natural beauty and unspoiled natural resources such as rocks, rock cliffs, flora, and fauna. Along the way down, Riam Sabada is dominated by large rocks, and there are sufficiently high rock cliffs. Visitors can do photography, camping, and hiking activities. Camping could be carried out on large and spacious rocks in safe conditions. The view of rice fields and the road to Riam Sabada tourism can also be an object of photography activities. The cleanliness of the Riam Sabada area needs to be maintained. There is non-organic waste polluting the environment and disturbing the scenery resulting in less cleanliness value [10]. 


\subsection{Accessibility}

Accessibility is an arrangement that considers the land use patterns with the transportation network as a link. The accessibility level at Riam Sabada has a potential enough category (B). The distance from the capital city to Sengah Temila District is approximately five hours by road using four-wheeled and two-wheeled vehicles. Travel time is more or less 30 minutes from the capital of Sengah Temila District to the Riam Sabada tourist attraction. The four-wheeled was only could get to Keranji Birah Hamlet with asphalt road, continued to two-wheeled vehicles to go to tourist attractions via concrete roads. Based on information from the Head of Keranji Birah Hamlet, there are community agricultural lands using aid funds from the National Community Empowerment Program (PNPM) in 2012 along the concrete road. Based on field observations, the road conditions to tourist attractions have potholes and have not been repaired since it was built in 2012. Accessibility is a primary requirement for a tourist attraction [11].

\subsection{Socioeconomic and Environmental Conditions}

The criteria for socioeconomic and environmental conditions in Riam Sabada are 585.7, indicating the poor possibility to be developed (C). There was no regional spatial arrangement and clarity regarding land status in the Riam Sabada tourist area. According to the community, the Riam Sabada is a part of the Bukit Samahung Protected Forest. A protected forest is a forest that functions as a protection for life support systems to regulate water systems, prevent flooding and seawater intrusion, erosion control, and maintain soil fertility [12]. Communities around the Bukit Samahung Protection Forest are allowed to farm within a radius of $10 \mathrm{~km}$ below the hill. This regulation can be used as a reference in the development of nature tourism objects Riam Sabada to improve the social and economic environment of the community.

In addition, the livelihoods of the people in Riam Sabada are farmers in general with an average education of high school graduates. The existence of the Riam Sabada tourist attraction should open up career and business opportunities for the surrounding community. However, the absence of spatial planning and clarity of land status, and inadequate human resources have made the tourism area undeveloped. The development of nature tourism in the Riam Sabada area is still in the planning process by the village government, but the community strongly supports the development of the Riam Sabada tourist attraction and expects to help their economy. The success of management depends on the support of the community and their perspective on environmental sustainability [13].

\subsection{Accommodation}

The assessment of accommodation criteria obtained a poor score $(\mathrm{C})$ because there were no hostelries provided for visitors in the Riam Sabada tourist area. Visitors who would like to stay could be used the house of family/acquaintances or the head of the hamlet or residents. Meanwhile, visitors from abroad usually stay at Rumah Betang, located in the hamlet of Saham Village, because the location is relatively close to Riam Sabada. According to [14], the 
accommodation in tourist attraction areas is beneficial for visitors when they want to stay at the locations visited.

\subsection{Supporting Infrastructure}

Supporting infrastructure in the Riam Sabada tourist area is insufficient. There are parking areas, drinking water networks, and telephone networks, while other infrastructure facilities are unavailable. Tourist areas should have adequate facilities and infrastructure to provide comfort for visitors. According to [15], the availability of facilities and infrastructure will encourage potential tourists to visit and enjoy natural attractions for a relatively long time.

Supporting infrastructure facilities that need to be built in the Riam Sabada tourist area include toilets, restaurants, souvenir stalls, and electricity networks. The provision of toilets is significant for the convenience of visitors where visitors can change clothes and maintain the water quality. The affordable restaurant at tourist attractions is also necessary, therefore the visitors do not need to bring their food. Garbage disposal sites must be provided in every corner. The construction and procurement of infrastructure facilities are notable but must be accompanied by maintenance and repairs to be utilized in the long term [16].

\subsection{Clean Water Availability}

The assessment of clean water availability in Riam Sabada tours obtains a good value (A). This area has a large volume (adequacy) of clean water (Figure 2) for visitors and the community in Keranji Birah Hamlet. The distance of clean water sources to the tourist area is relatively close. However, the availability needs to be improved because its position is below the area used by visitors.

Communities around the tourist attraction consume water directly or by cooking. Therefore, the source of clean water in Riam Sabada is always available throughout the year, even during the dry season. As stated by [17], the availability of clean water is an important thing in the tourism sector.
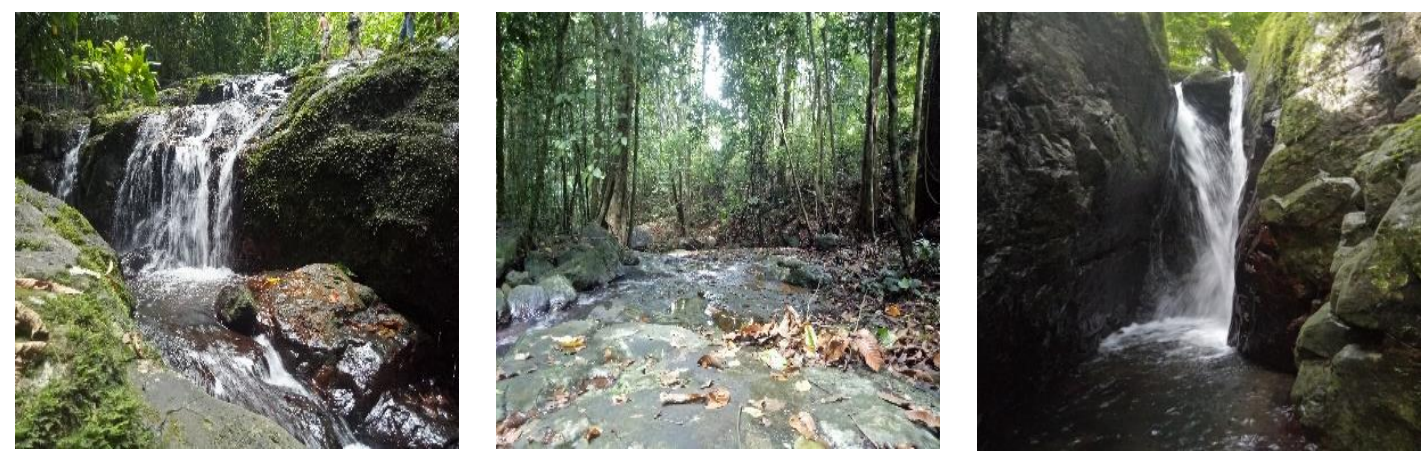

Figure 2 Condition of rocks and clean water in the Riam Sabada 


\subsection{Riam Sabada Tourism Development Strategy}

Based on the results of the tourism potential assessment and direct observation along with interviews with respondents, the internal factors (weaknesses and strengths) and external factors (opportunities and threats) were obtained. The internal and external factors are as follows.

Table 3 Internal and External Factors

\begin{tabular}{|c|c|c|}
\hline \multirow{2}{*}{$\begin{array}{l}\text { Internal } \\
\text { factors }\end{array}$} & Strengths & Weaknesses \\
\hline & $\begin{array}{l}\text { 1. The beauty and integrity of the } \\
\text { Riam Sabada tourist attraction } \\
\text { 2. The amount of public interest in } \\
\text { the development of the Riam } \\
\text { Sabada tourist attraction } \\
\text { 3. There are several visitors from } \\
\text { outside the province and even } \\
\text { abroad } \\
\text { 4. Abundant water sources }\end{array}$ & $\begin{array}{l}\text { 1. Roads in tourist attraction areas are } \\
\text { still inadequate } \\
\text { 2. Do not have sufficient capital to } \\
\text { the development of tourism objects } \\
\text { 3. Do not have the capacity of human } \\
\text { resources } \\
\text { 4. Lack of facilities and infrastructure } \\
\text { 5. There are no lodging facilities }\end{array}$ \\
\hline \multirow{2}{*}{$\begin{array}{l}\text { External } \\
\text { Factors }\end{array}$} & Opportunities & Threats \\
\hline & $\begin{array}{l}\text { 1. Increase in the number of tourist } \\
\text { interest in nature tourism } \\
\text { 2. There are other activities as a } \\
\text { companion attraction } \\
\text { 3. Procurement of admission tickets } \\
\text { 4. Potential for souvenirs } \\
\text { 5. There is a local government plan } \\
\text { to develop the tourist attraction }\end{array}$ & $\begin{array}{l}\text { 1. The competition for nature tourism } \\
\text { is slightly high } \\
\text { 2. Spatial conflict with the } \\
\text { agricultural sector } \\
\text { 3. Environmental pollution by cutting } \\
\text { down trees on a small scale } \\
\text { 4. The rainfall is rather high }\end{array}$ \\
\hline
\end{tabular}

The internal and external factors values are +0.45 and +0.21 , respectively (Figure 2 ). Thus, if it is included in the Grand Strategy Matrix, it shows that the position of the Riam Sabada natural tourism object is in quadrant I or an aggressive strategy (SO strategy). This position states that the natural attractions of Riam Sabada are in a favorable situation, namely having opportunities and strengths so that they can take advantage of existing opportunities [18]. Therefore, opportunities should be utilized by increasing their strengths.



Figure 3 Position of Riam Sabada Area in the SWOT Analysis Quadrant 
Policy strategies that support aggressive strategies to be implemented in the development of nature tourism objects Riam Sabada are as follows:

a. Evolve the potential of natural resources. The evolvement must be the unique tourism activities, such as camping and photography facilities.

b. Establish cooperation between the community, managers, and stakeholders. Collaboration with the private sector is necessary to harmonize the implementation of tourism, especially in providing the facilities, infrastructure, and services [19].

c. Increase the publication and promotion of Riam Sabada tourism. The promotion can be done by optimizing the social media networks.

d. Provide sufficient facilities and infrastructure, including toilets, parking areas, ticket booths, canteens, and souvenir stalls. Besides that, homestays are also fundamental so that visitors can enjoy the beauty of nature for a long time.

\section{Conclussion}

The internal and external factors values were +0.45 and +0.21 in quadrant $I$ or an aggressive strategy. Therefore, the strategy of increasing the growth rate of tourist visits was a priority, and quality improvement of the present potential was a strong factor to maximize the utilization of all opportunities. The policy strategies suggested were (a) Developing the present potential of natural resources, (b) Establishing cooperation between local communities, managers, and stakeholders, (c) Increasing publication and promotion of Riam Sabada tourism, and (d) Providing sufficient facilities and infrastructure.

\section{REFERENCES}

[1] F. D. C. Nurhadi, Mardiyono and S. P. Rengu, "Strategi pengembangan pariwisata oleh Pemerintah Daerah terhadap pendapatan asli daerah," Jurnal Administrasi Publik (JAP), vol. 2, no. 2, pp. 325-331, 2014.

[2] Pendit, Ilmu Pariwisata: Sebuah Pengantar, Perdana, Jakarta, 2006.

[3] O. A. Yoeti, Pemasaran Pariwisata, CV. Angkasa, Bandung, 2013.

[4] Aristo, S. Rifanjani and S. Latifah, "Penilaian daya tarik objek wisata alam Riam Angan Tembawang di Desa Angan Tembawang Kecamatan Jelimpo Kabupaten Landak," Jurnal Hutan Lestari, vol. 8, no. 1, pp. 193-197, 2020.

[5] A. Julianto, H. S. Zainal and Fahrizal, "Faktor pendukung pengembangan objek wisata Air Terjun Mananggar di Dusun Tauk Kecamatan Air Besar Kabupaten Landak," Jurnal Hutan Lestari, vol. 5, no. 2, pp. 307-312, 2017.

[6] P. Yupensius, Kartikawati and H. Prayogo, "Potensi daya tarik objek wisata Air Terjun Dait di Desa Sekendal Kecamatan Air Besar Kabupaten Landak," Jurnal Hutan Lestari, vol. 5, no. 4, pp. 1094-1099, 2017.

[7] K. Wigo, S. Rifanjani and R. S. Wulandari, "Penilaian daya tarik objek wisata Riam Sabada Desa Sebatih Kecamatan Sengah Temila," Jurnal Hutan Lestari, vol. 8, no. 3, pp. 566-575, 2020.

[8] P. H. d. K. A. (PHKA), Pedoman Analisis Daerah Operasi Objek Daya Tarik Wisata Alam (ADO-ODTWA), Direktorat Jenderal Perlindungan Hutan dan Konservasi Alam, Bogor, 2003. 
[9] K. Madjid, Sangkertadi and S. Supardjo, "Analisis Potensi Pengembangan Objek Wisata Pantai Tugulufa Kota Tidore," Jurnal Spasial, vol. 6, no. 2, pp. 312-320, 2019.

[10] S. I. P. Barus, P. Patana and Y. Afiffudin, "Analisis objek wisata dan kesiapan masyarakat dalam pengembangan desa wisata berbasis masyarakat di kawasan Danau Linting Kabupaten Deli Serdang," Peronema Forestry Science Journal, pp. 143-151, 2013.

[11] Dimas, Fahrizal and Iskandar, "Peran Masyarakat Desa Senakin dalam pengelolaan wisata Riam Solakng sebagai kawasan wisata alam di Kecamatan Sengah Temila Kabupaten Landak," Jurnal Hutan Lestari, vol. 5, no. 2, pp. 177-182, 2017.

[12] Peraturan Menteri Lingkungan Hidup dan Kehutanan Republik Indonesia Nomor P.50/Menlhk/Setjen/Kum.1/6/2016 tentang Pedoman Pinjam Pakai Kawasan Hutan, 2016.

[13] S. Purwanto, L. Syaufina and A. Gunawan, "Kajian potensi dan daya dukung Taman Wisata Alam Bukit Kelam untuk strategi pengembangan ekowisata," Jurnal Pengelolaan Sumberdaya Alam dan Lingkungan, vol. 4, no. 2, pp. 119-125, 2014.

[14] I. A. Ginting, P. Patana and Rahmawaty, "Penilaian dan pengembangan objek dan daya tarik wisata alam di Taman Wisata Alam (TWA) Sibolangit," Peronema Forestry Science Journal, vol. 2, no. 1, pp. 74-81, 2013.

[15] S. Abdulhaji and I. S. H. Yusuf, "Pengaruh atraksi, aksesibilitas, dan fasilitas terhadap citra objek wisata Danau Tolire Besar di Kota Ternate," Jurnal Penelitian Humano, vol. 7, no. 2, pp. 134-148, 2016.

[16] F. Delita, Elfayetti and T. Sidauruk, "Analisis SWOT untuk strategi pengembangan objek wisata Pemandian Mual Mata Kecamatan Pematang Bandar Kabupaten Simalungun," Jurnal Geografi, vol. 9, no. 1, pp. 41-52, 2017.

[17] A. A. P. Dwijayani and W. Hadi, "Studi kelayakan pengelolaan air laut menjadi air bersih di Kawasan Wisata dan Pelabuhan Perikanan Nusantara (PPN) Pantai Prigi Trenggalek," Jurnal Teknik ITS, vol. 2, no. 2, pp. 63-68, 2013.

[18] F. Rangkuti, "Analisis SWOT Teknik Membedah Kasus Bisnis," in Cetakan keduabelas, Jakarta, PT. Gramedia Pustaka Utama, 1997.

[19] W. Zulfikar, "Model Kerjasama Academic, Business, Goverment dan Civil Society Pada Kebijakan Kertajati Aerocity," Jurnal Caraka Prabu, vol. 3, no. 2, pp. 169183, 2019. 